\title{
Duszpastersko i społecznie bardzo potrzebny
}

Arcybiskup Celestino Migliore

Nuncjusz Apostolski w Polsce

Warszawa, 16 stycznia 2016

Cieszę się, że przynamniej w ten sposób mogę wziąć udział w wydarzeniu upamiętniającym osobę Arcybiskupa Życińskiego. Podczas mojego pierwszego pobytu w Polsce został biskupem tarnowskim, a potem przyszło mi jako nuncjuszowi w Polsce uczestniczyć w jego ostatnim pożegnaniu.

Często mówiło się o Józefie Życińskim, że był urodzonym naukowcem. Dodałbym jeszcze: i urodzonym dydaktykiem. Wiem od wielu osób, że na jego wykłady w Krakowie przychodziły tłumy, i to nie tylko adeptów filozofii przyrody. Lubiono, gdy mówił, bo jego przekaz był jasny, Arcybiskup posługiwał się przystępnym językiem, cechowały go swoisty dowcip i błyskotliwość erudyty.

A później - jak to możemy docenić dopiero po czasie był urodzonym pasterzem i uczestnikiem życia społecznego. To, czego dopracował się w trakcie poszukiwań naukowych, umiał zastosować w swoich pasterskich kontaktach 
z ludźmi. Tytuł jego pracy habilitacyjnej to Prostota i dyskonfirmowalność jako kryteria heurystyczne w kosmologii relatywistycznej. Czyż w jego posłudze biskupiej można było nie dostrzec prostoty? Rozumianej oczywiście nie jako uproszczenie intelektualne czy moralne, ale jako umiejętność wchodzenia w dialog ze wszystkimi, także z tymi, z których poglądami nie mógł się identyfikować. A dyskonfirmowalność? Kto inny tak błyskotliwie i dowcipnie potrafił pokazywać, jak nie do utrzymania są pozycje ideologiczne, aracjonalne, wykluczające się a priori?

W miejsce eliminacji i przeciwstawień wprowadzał komplementarność, bo tak naprawdę taka właśnie postawa jest bliższa Ewangelii. Stąd swoje biskupie zawołanie oparł na Duchu i Prawdzie. Wiedział, że ewangelizacja dokonuje się w kontekście życia społecznego i nowych zjawisk, które w tym życiu się pojawiają. Często był więc o krok do przodu, co nie zawsze jest powszechnie akceptowane, ale duszpastersko i społecznie bardzo potrzebne.

Gdybyśmy w Duchu i Prawdzie bardziej widzieli komplementarność pewnych postaw, niż patrzyli na nie jako na coś, czemu trzeba się niemalże siłowo przeciwstawiać i co trzeba eliminować, życie byłoby nie tylko łatwiejsze, ale przede wszystkim prawdziwsze. Może właśnie to jest przesłaniem pozostawionym nam przez Arcybiskupa Życińskiego, urodzonego naukowca, dydaktyka, a przede wszystkim pasterza. 